\title{
SOME REMARKS ON THE REALIZATION OF EUROPEAN POLICY FOR ENERGY EFFECTIVENESS OF BUILDINGS
}

\author{
Lubomir Bonev $^{1}$ And YatctKo Ivanov ${ }^{2 *}$ \\ ${ }^{1}$ 1, Vassil Stoin St., Bl. 4, Pernik, Bulgaria, \\ e-mail: lubobonev@abv.bg \\ ${ }^{2}$ Institute of Mechanics, \\ Bulgarian Academy of Sciences, \\ Acad. G. Bonchev St., Bl. 4, 1113 Sofia, Bulgaria, \\ e-mail: yadir_1@abv.bg
}

\begin{abstract}
Now we are at the end of the term of performance of the Directive 2010/31/EC for energy effectiveness of buildings. Republic of Bulgaria in accordance with this Directive has promoted national plan for near zero energy building (2015-20220). The realization of the ideas of these documents is the object of consideration. A special attention is paid to the sustainable development of building construction and on realization of national program for energy effectiveness. Subsequent conclusions and recommendations are presented.

Keywords: building, remediation, energy effectiveness, national plan, Near Zero Energy Building (NZEB).
\end{abstract}

\section{INTRODUCTION}

In March 2007 the European Council (EC) has announced the necessity of increasing of energy efficiency and to achieve $20 \%$ reduction of energy consumption by 2020. The European Parliament (EP) in January 2008 issued a directive mandating these recommendations. In $2009 \mathrm{EP}$ and EC published mandatory national targets of decreasing the emissions. At the beginning of the second decade of 21 Century EP and EC with Directive 2010/30/EU encouraged the use of energy from renewable sources. After that in the same year EP and EC have accepted Directive 2010/31/EC, which encouraged the improvement of the characteristics of new and old buildings in the EU accounting climate and the local conditions, as well the requirement to the ambient

${ }^{*}$ Corresponding author.

DOI: 10.7546/EngSci.LVII.20.02.04

Engineering Sciences, LVII, 2020, No. 2 
air having in mind basic ratio "cost efficiency". According to this Directive all member-countries have been obliged to attain nearly zero net energy consumption in all old and public buildings up to the end of 2018. For the new buildings this obligation was fixed up to the end of 2020. In Strategy Europe 2020, energy efficiency becomes one of seven leading initiatives of strategy "Europe for effective use of resources". The politics of EU for energy effectiveness is presented in Directive 2012/27/EC. The new Directive 2018/844/EC of EP and EC from 30 May 2018 changes Directive 2010/31/EC and 2012/27/EC, in which new demands for planning and accounting of the national strategy for renovation and creation of national plans and travel card for the realization of EC politics for energy effectiveness up to 2050 are presented.

All these decisions of EP and EC are in direct contact with the actions for the safety measures of sustainable development in the different fields of human beings activities and climate changes. For this reason the new team of EC announces as very urgent the problems of carbon certainty up to 2050 and proposes one "green package", in which to include "first European legislation for climate" to achieve climatic neutrality at 2050 and decrease of emissions of $\mathrm{CO}_{2}$ with $50 \%$ and if possible with $55 \%$ at 2030 [1]. These plans of EC present also very big provocations to all our activity, including building industry. Special Recommendation 2019/786 of EC indicates that central place in the politics of Commission is addressed to the buildings which consume near $40 \%$ of all consumption of finale energy [2]. In this document EC underlines the importance of energy efficiency and the role of construction branch for the reach of the goal of the Union in the field of energetics and climate, as well as for the transition to pure energy. It is underlined that the action for energy efficiency must play central role in achievement of neutral economy towards climate up to 2050 and to decrease at half of energy consumption in comparison with 2005. This new goal demands accelerated extensive repair of existing buildings and to help modernization of all buildings with intelligent technologies. New data for qualities of buildings are needed, as well generation of new basis data for the goal of certification of energetic characteristics these data can be used for the preparation of statistics of regional and national buildings found. These actions are needed financial measures which must be related with the quality of the repair in the context of the obtained economy of energy with the remediation. 


\section{BULGARIAN NORMATIVE DOCUMENTS FOR THE REALIZATION OF EUROPEAN POLICY OF ENERGY EFFECTIVENESS}

1) Regulation No 7 of 2007 for Energy efficient performance of buildings (Modified title - Official Gazette (OG) No 85 of 2009, Modified - OG, No 27 of 2015, in operation since 15.07.2015 issued by the Ministry of Regional Development and Public Works. In the Regulation the following requirements are included: minimal requirements to the energy efficient performance of residential and public buildings and technical requirements to their energy characteristics, as well as the methods for their calculation; limit values of the introduced parameter "specific annual consumption of primary energy" as a $\mathrm{kWh} / \mathrm{m}^{2}$; coefficient of heat requirements to moisture resistance, air conductivity, water resistance, sumer solar protection, technical requirement to heating/cooling generators including decentralized systems for utilization of energy from renewable sources; requirement to investment projects sestimating the energy consumption.

2) Law for energy efficiency (published in OG No 35 of 15.05.2015). This law regulates public regulations in implementations of the Bulgarian official policy of increasing energy efficiency as a part of sustainable development by: the use of systems which increase energy efficiency during consumption; generation, transfer and distribution of energy and consumption by final users; applications of systems for energy saving; development of new market ensuring energy efficient service and stimulation of its offer; introduction of financial mechanisms and schemes that will help realization of the national task of construction of energy efficient buildings.

3) New Regulation, which is modifying and giving supplementary rules in the Regulation No 15 of 2005 - about technical rules and normative documents for design, manufacture and exploitation equipment and units for generation, transfer and distribution of thermal energy (published in OG No 68 of 2005).

4) Elaborated National Plan (NP), developed in conformity with Article 9, Paragraph 1 of the Directive 2010/31/EU, for Near Zero Energy Building (NZEB) and published in 2015 as a Regulation No 1035 of the Council of Ministers, which is oriented to the introduction of this concept in 2018 as one applicable alternative for new and existing buildings.

5) Regulation E-RD-04-1: Inquiry for energy efficiency certification and assessment of buildings. This document specifies the conditions and order of emitting of certificate for energy characteristics, investigation of energy

Engineering Sciences, LVII, 2020, No. 2 
efficient performance of buildings during their exploitation, delivering of certificate after cited investigation and estimation of energy saving.

6) Regulation E-RD-04-2: Presenting the parameters of energy consumption and energy characteristics of buildings. It gives conditions for indentifying the parameters of building energy consumption and energy characteristics; methodology of the formation of consumption parameters and building characteristics; parameters of the scale of energy consumption classes for the categories of buildings; limit value of the integrated energy parameter "Specific annual consumption of primary energy", $\mathrm{kWh} / \mathrm{m}^{2}$, which is specified by the subsequent scale of energy consumption classes.

\section{RESULTS IN REALIZATION OF NATIONAL PLAN FOR NEAR ZERO ENERGY BUILDING}

\subsection{Execution of European policy}

The initial requirement of EC to the member-countries was to formulate their own clear national definition of NZEB in conformity within the general framework of the Directive 2010/31/EU - "NZEB means a building with very good energy characteristics. The necessary amount with nearly zero or very low cost should be generated to a significant extent from renewable energy sources, including sources located in situ or in close vicinity". The report of EC to the EP $[4,5,6]$ stated that by July 2013 Bulgaria was one of the countries that had no a definition of NZEB. Some years later in the Energy Efficiency Law [7] it was given as "NZEB is a building which simultaneously meets the following requirements: (i) energy consumption specified as a primary energy consumption should correspond to class A of the scale of classes of the energy consumption of buildings of respective type; (ii) not less than $55 \%$ of the energy used for heating, cooling, ventilation, heating of water for daily needs and illumination should come from renewable sources located in situ (at "building" level) or in close vicinity". This definition is a result of some simulations and takes into account the research of energy efficient performance of local buildings, Table 1.

After that the parameters of energy consumption and energy characteristics of buildings have been established taking into account: orientation, dimension and shape, systems for air and water heating, cooling, ventilation and illumination, as well as building specific functions [3]. As a result of this work now we have a series of normatives for energy consumption of different types 
Table 1. Group of buildings

\begin{tabular}{|c|c|}
\hline Building groups & $\begin{array}{l}\text { Requirements for meeting nearly zero } \\
\text { energy emission standard }\end{array}$ \\
\hline $\begin{array}{l}\text { Group A: Single and multi-occupancy } \\
\text { residential buildings with a floor area } \\
\text { of up to } 500 \mathrm{~m}^{2}\end{array}$ & $\begin{array}{l}\text { 1) To achieve class A primary energy } \\
\text { consumption whereby: } \\
\text { 2) At least } 50 \% \text { of the energy needed for } \\
\text { heating, hot water, ventilation and } \\
\text { cooling is from renewables }\end{array}$ \\
\hline $\begin{array}{l}\text { Group B: Buildings with a floor space } \\
\text { from } 500 \text { to } 7000 \mathrm{~m}^{2} \text { - residential build- } \\
\text { ings, halls of residence, rest houses, } \\
\text { multifunction buildings, public build- } \\
\text { ings for education and science, cul- } \\
\text { ture, social services, administration, } \\
\text { commerce, public catering and hotels, } \\
\text { buildings for domestic services, public } \\
\text { service buildings for transport and elec- } \\
\text { tronic communications, sports, ceremo- } \\
\text { nial buildings, congress and conference } \\
\text { centres, and health establishments. }\end{array}$ & $\begin{array}{l}\text { 1) To achieve class A primary energy } \\
\text { consumption whereby: } \\
\text { 2) At least } 30 \% \text { of the energy needed for } \\
\text { heating, hot water, ventilation and } \\
\text { cooling is from renewables. } \\
\text { 3) The share of electricity in the build- } \\
\text { ing annual primary energy con- } \\
\text { sumption balance (including elec- } \\
\text { tricity for heating, hot water, ven- } \\
\text { tilation and cooling systems) is not } \\
\text { more than } 30 \% \text {. }\end{array}$ \\
\hline $\begin{array}{l}\text { Group C: Buildings with a floor space of } \\
\text { more than } 7000 \mathrm{~m}^{2}-\text { residential build- } \\
\text { ings, halls of residence, rest houses, } \\
\text { multi-function buildings, public build- } \\
\text { ings for education and science, cul- } \\
\text { ture, social services, administration, } \\
\text { commerce, public catering and hotels, } \\
\text { buildings for domestic services, public } \\
\text { service buildings for transport and elec- } \\
\text { tronic communications, sports, ceremo- } \\
\text { nial buildings, congress and conference } \\
\text { centres, and health establishments. }\end{array}$ & $\begin{array}{l}\text { 1) To achieve class A primary energy } \\
\text { consumption, whereby: } \\
\text { 2) At least } 20 \% \text { of the energy needed for } \\
\text { heating, hot water, ventilation and } \\
\text { cooling is from renewables. } \\
\text { 3) The share of electricity in the build- } \\
\text { ing annual primary energy con- } \\
\text { sumption balance (including elec- } \\
\text { tricity for the heating, hot water, } \\
\text { ventilation and cooling systems) is } \\
\text { no more than } 40 \% \text {. }\end{array}$ \\
\hline
\end{tabular}

of buildings. Figure 1 shows the normative for residential and administrative buildings $[3,6]$.

A comparison of our normative for energy consumption with that accepted in some European countries indicates that it is comparable to normative in Slovenia but its value is lower than that in Sweden and Poland. In the same time we have to note that our normative for class A+ is not corresponding to the requirement for green/passive buildings for which this standard requirement is for values less than $15 \mathrm{kWh} / \mathrm{m}^{2}$ [8]. Only residential buildings class $\mathrm{A}+$ with EPmax $=48 \mathrm{kWh} / \mathrm{m}^{2}$ can be classified as low energy consumption buildings. 


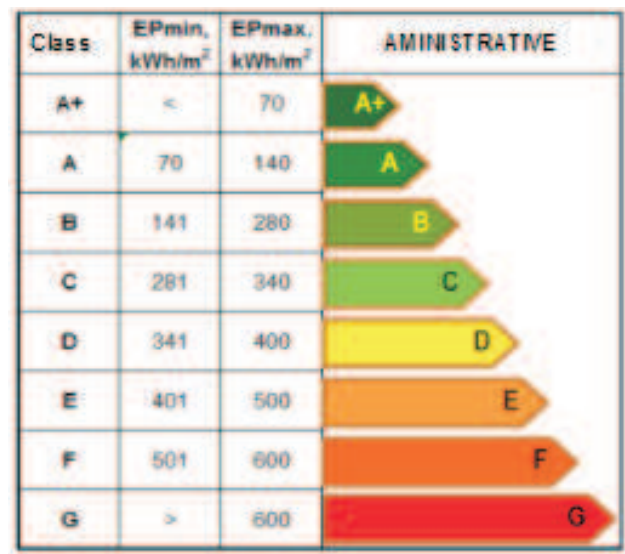

(a)

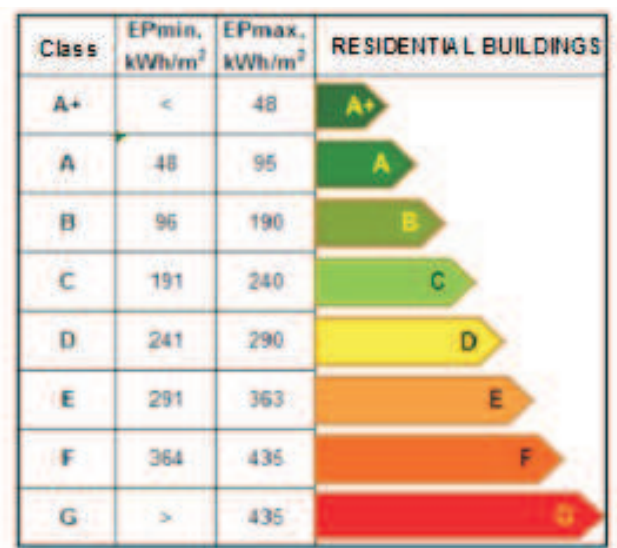

(b)

Fig. 1. Minimal (EPmin) and maximal (EPmax) consumption of electric power for: (a) administrative buildings; (b) residential buildings

\subsection{The execution of National plan of attaining energy efficiency and remediation of buildings}

The goal, parameters and development of National Plan of energy efficiency of old and new buildings up to 2020 are presented in [4-6] - there are two action plans. Bulgarian building branch is structure, determining for our economy, it is also a stimulus for attraction of investments. By its actions in the field of remediation Bulgarian building branch has important role for the increase of energy efficiency of the buildings and for the positive changes of quality of habitation and working environment. The data for the energy efficient performance is given in the annual reports (2016-2019) of the National Agency for Sustainable Energy Development (NASED) [9-12]. According to the data of NASED in Bulgaria buildings for public services have $104923286 \mathrm{~m}^{2}$ Open Build Area (OBA) and the residential ones - $240614647 \mathrm{~m}$. From the annual reports of the Agency as example the results for the investigated buildings are given (Table 2), as well evaluation declared for efficiency (Table 3) by the South-West economic and planning region of Bulgaria, and the rapport for the realization of the program for the energy efficiency (2016-2019) in the district Pernik of this region (Table 4).

The data given in Tables 2 and 3 shows that during these four years the decrease of investigated buildings is seen. From the data cannot be concluded how many are administrative buildings, which according to the EU Directive have been planned to be remediated up to the end of 2018. It is also impossible 
Table 2. Expected results from the investigated buildings in the South-West economic and planning region of Bulgaria

\begin{tabular}{|l|c|c|c|c|c|}
\hline Results & 2016 & 2017 & 2018 & 2019 & Total \\
\hline Number of investigated buildings & 544 & 373 & 356 & 90 & 1363 \\
\hline Open build area $-\mathrm{m}^{2}$ & 66021 & 29758 & 35915 & 206437 & 338031 \\
\hline Economized fuel and energy - MWh/year & 15255 & 17676 & 8561 & 4955 & 46447 \\
\hline Economized $\mathrm{CO}_{2}$ emission - tone/year & 4179 & 7516 & 7455 & 1429 & 20540 \\
\hline
\end{tabular}

Table 3. Evaluation of the declared effect from the realized $\mathrm{ECM}^{*}$ for $2016-2019$ in the South-West economic and planning region of Bulgaria

\begin{tabular}{|l|c|c|c|c|}
\hline Results & 2016 & 2017 & 2018 & 2019 \\
\hline Number ECM & 544 & 373 & 356 & 269 \\
\hline Investment - thousand. BGL/year & 66021 & 27758 & 35915 & 26119 \\
\hline Economized fuel and energy - MWh/year & 15255 & 17676 & 8561 & 5376 \\
\hline Economized investment thousand BGL/year & 2388 & 2734 & 1579 & 586 \\
\hline Economized $\mathrm{CO}_{2}$ emission tone/year & 6717 & 7516 & 4179 & 1938 \\
\hline
\end{tabular}

*ECM - for fencing elements, heating and ventilation, air-conditioning, systems for measuring of automation, heating and lighting installations (without gasification and the use of RES.)

Table 4. Report for the realization of the program for the energy efficiency (2016-2019) for district Pernik (South-West Region)

\begin{tabular}{|c|c|c|c|c|c|}
\hline Implement & Number & Investment & \multicolumn{3}{|c|}{ Economized } \\
\cline { 4 - 6 } $\begin{array}{c}\text { Buildings } \\
\text { for years }\end{array}$ & ECM & $\begin{array}{c}\text { thousand } \\
\text { BGL }\end{array}$ & $\begin{array}{c}\text { Fuel and } \\
\text { energy } \\
\text { MWh/year }\end{array}$ & $\begin{array}{c}\text { Investment } \\
\text { thousand } \\
\text { BGL }\end{array}$ & $\begin{array}{c}\text { Emission } \\
\mathrm{CO}_{2} \\
\text { t/year }\end{array}$ \\
\hline 2016 & 192 & 11077 & 5557 & 915 & 2011 \\
\hline 2017 & 66 & 4233 & 953 & 285 & 376 \\
\hline 2018 & 61 & 5665 & 1004 & 755 & 307 \\
\hline 2019 & 68 & 7522 & 1148 & 106 & 296 \\
\hline Total & 387 & 38135 & 8660 & 2101 & 2990 \\
\hline
\end{tabular}


to evaluate how is the situation for remediation of buildings constructed by the use of big panels. Our investigations show that only municipality Troyan is finished the remediation of all administrative buildings and in addition 10 numbers large family buildings have been remediated. For the country up to now investigated buildings are with open build area less than 2 million, i.e. we are far away of the area sited at the beginning of this part of the article.

The conclusions from Tables 2 and 3 are also applicable for the results of the activity in district Pernik, which is one of the five districts of $\mathrm{S}-\mathrm{W}$ region of Bulgaria. According to the article 12 (5 and 6) and article 63 (4) of the Law for Energy Efficiency (LEE) the organs of state authority and local administrations present their annual reports for the realization of the programs for EE up to 01 March of the next year. For example in the district of Pernik for 2019 only $75 \%$ of needed reports are presented, and some of them are not in the recommended form and content.

In the data in the reports of NASED cannot be seen how many of remediated buildings are administrative or residential, which are built by the use of big prefabricated elements technology. Nothing can be seen for the passports and correspondence of renewed buildings to the standard for energy efficiency. The Directives of EU, which are on the basis of our national Laws and Recommendations, are ordered after 2020 all residential and administrative buildings to be class A in their characteristics for energy effectiveness, but in the Bulgarian annual reports these data are missing.

There are a number of construction practices showing satisfactory results, which are a model for the realization of the idea of NZEB. Some examples in Bulgaria [3]: day nursery "Slantse" in Gabrovo, Fig. 2 - the first building in Bulgaria designed and constructed in conformity with the standard NZEB; Art gallery in Burgas; Sofia Airport Center, Fig. 3 - first building with green roof and first buildings with gold certificate for sustainability LEED Gold; Grand Canyon in Sofia, etc. During the studied period the following buildings are finished: Fort Building in Sofia, Fig. 4 - business center, offices class A, noteworthy concurrent of financial business centers in the world; Office building, Fig. 5, which implements all standard for NZEB (class A+), and Family building constructed in Sofia by German company [13] using new technology with wood elements and characteristic corresponding to passive house (class A). 


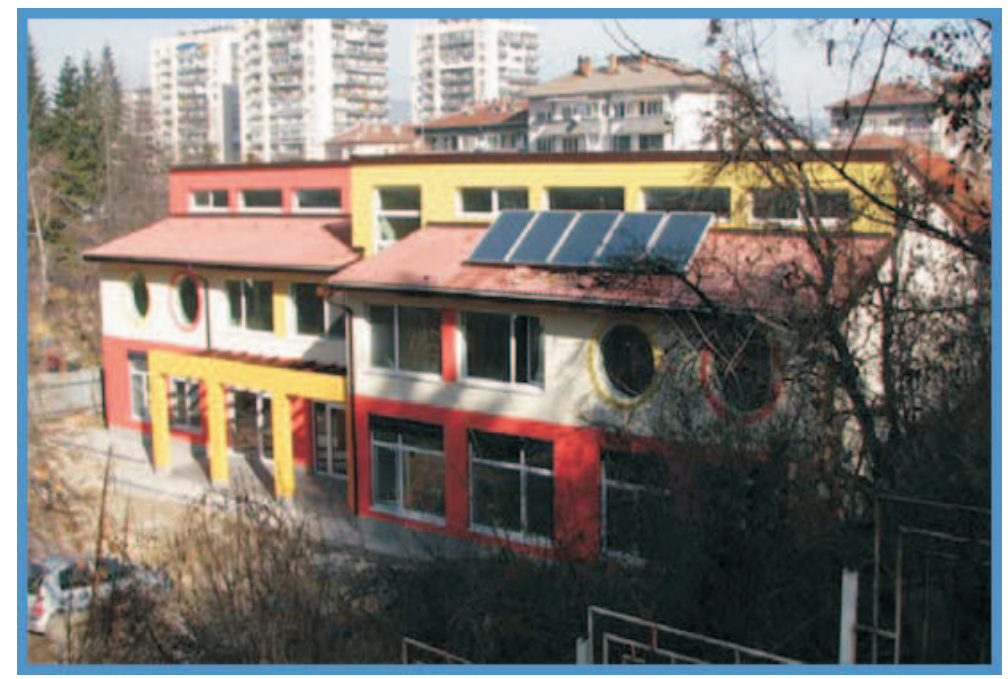

Fig. 2. Nursery "Slantse" - Gabrovo

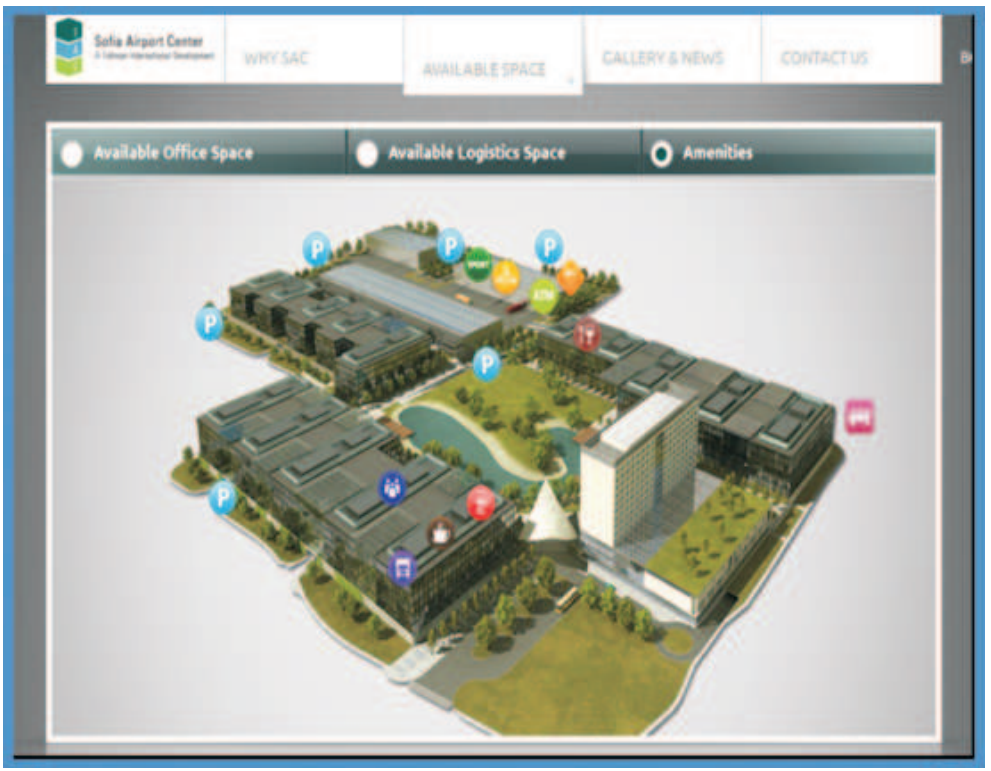

Fig. 3. Sofia Airport Center

Engineering Sciences, LVII, 2020, No. 2 


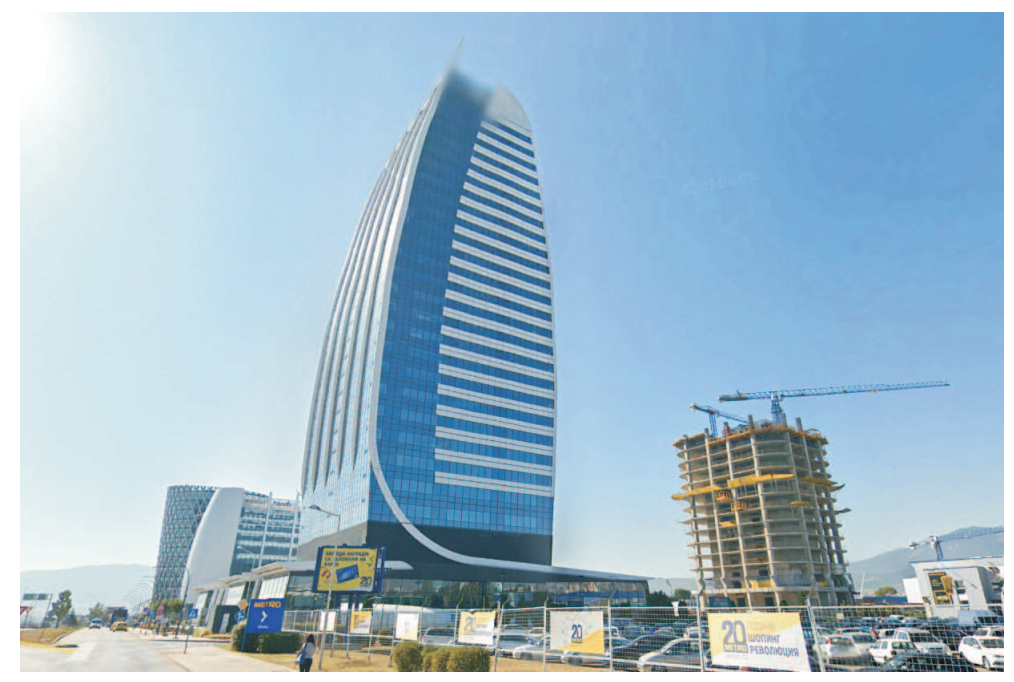

Fig. 4. Capital Fort Building in Sofia (left)

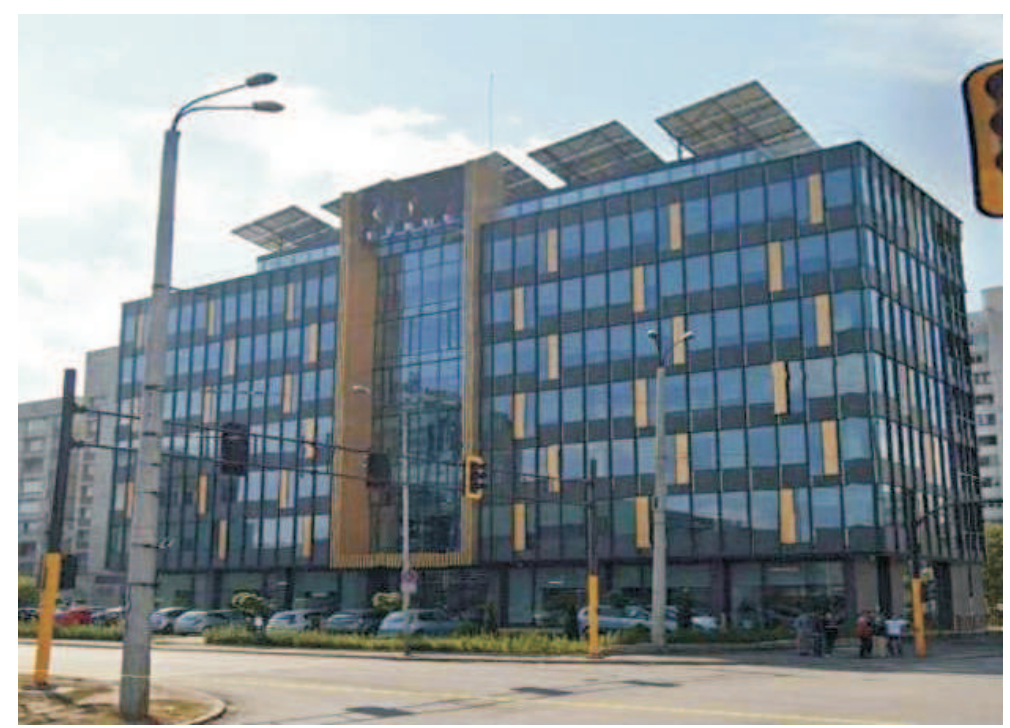

Fig. 5. Office building in Sofia (NZEB with renewable energy) 


\subsection{Some innovative directions and barriers for realization of politics for energy efficiency and remediation of buildings}

In new construction practice many innovative technologies and materials exist. First of all applications of renewable photo-voltaic electric sources must be introduced. Now it is possible to have solar systems for individual users these investments can be returned for 6- 8 years by the economy of expenditure for electricity, as well as by the selling of electricity. The more preferred configurations for personal use are small ones $(3-5 \mathrm{kWp})$. Their advantages are: simple construction; easier prognosis of expenditure for electricity; single investment with good return (about 8-13\%); independent day and hour control and diminished maintenance. According to the decision of the Commission for energy and water (2019) the energy from FWS with power up to $30 \mathrm{kWp}$ installed on the roof on the frontage and attached to the electrical distribution network is economically very favorable. The Second possibility is the use of green roof and the frontage in buildings - they can help climate regulation. The Third possibility is related with the orientation of buildings in the space - it can be useful for the economy from heating and lighting.

Between the barriers can be enumerated:

A. Organizational and financial factors

- Omission of the popular persuasion of the state way is needed remediation of old big residential buildings and which will be benefit for the owners of apartments;

- Long and difficult process of announcement, approval by a public commission and the receiving of finances, as well as disburse with builders;

- Difficulty in the analysis of living cycle of renewed buildings;

- Absence of technical passports for buildings - up to now only $5 \%$ of buildings in Bulgaria have such passports.

- Important difficulty is the fact that $1 / 3$ of the Bulgarians heat up their houses with not ecological and low calories firing.

- Omission of results for the changes in living conditions in the apartments of residential buildings and in productivity of people, working in remediated administrative buildings;

B. Research factors

- Lack of sufficient research of the changes in the internal ambiance of buildings after remediation, including comfort and safety (health);

- Lack of legal investigation and creation of needed norms;

- Lack of priority and finances for the needed researches;

- Lack of one effective management model for the realization of remediation

Engineering Sciences, LVII, 2020, No. 2 
and decarbonization of buildings. This management model must take into account the possibility of house owners.

\section{CONCLUSION}

The actual state of the NZEB approach and the recent advance in the realization in Bulgaria of the European politics for energy efficiency of buildings are outlined. The actual state of the implementation of the Directive 2010/31/EU and our corresponding National Plan are analyzed too. For the successful realization of the goal of programs which have to be reached up to 2050 are needed some short-dated actions:

- To develop national conceptions for the development of the Strategy for renovation of building found and passage to energy efficient (NZEB) buildings;

- To organize the managed campaign for passportization of all old buildings.

- To organize and start evaluation, certification and presenting the passports for remediated buildings;

- To start immediately a new campaign for presenting the advantages of this type of construction;

- To start work for real performance of Directive of EU, the Bulgarian laws and regulations for energy efficiency of new and old buildings, including residential private one.

- To stimulate scientific researches in the field of sustainable development of construction with high energy effectiveness.

\section{REFERENCES}

[1] YA. Ivanov, Engineering Sciences (2019) LVI (4) 30-42, ISSN: 1312-5702.

[2] Recommendation 2019/786 of EC from 8 May 2019 for remediation of buildings, Inf. No C (2019) 3352.

[3] G. Nikolova, A. Yanakiva, Ya. Ivanov, and R. Cazandjiev, in: Proceedings of Int. Conf. ESI'2017, pp.139-149.

[4] http://dv.parliament.bg/DVWeb/showMaterialDV.jsp.jsesionid= 1099350782990448C990932D20212D61?idMat $=94263$

[5] A. Yanakiva, G. Nikolova, and Ya. Ivanov, in: Proceedings of Int. Conf. ESI'2015, pp. 13-20.

[6] G. Nikolova, A. Yanakieva and Ya. Ivanov, in: Proceedings of Int. Conf. DCB'2015, pp. 31-43 
[7] http:/ec.europa.eu/energy/sites/ener/files/document/BG\%202016\%20Energy Efficency\%20Annual\%20Report_bg.pdf.

[8] T. Stoychev, Innovation in buildings, Science and economy publ. Univ. of Economy, Varna (2014), ISBN: 978-954-21-0771-2 (in Bulgarian).

[9] Analysis for the realization of municipalities and districts programs for energy efficiency in 2016 for regions of economic planning in Bulgaria (in Bulgarian).

[10] Analysis for the realization of municipalities and districts programs for energy efficiency in 2017 for regions of economic planning in Bulgaria (in Bulgarian).

[11] Analysis for the realization of municipalities and districts programs for energy efficiency in 2018 for regions of economic planning in Bulgaria (in Bulgarian).

[12] Analysis for the realization of municipalities and districts programs for energy efficiency in 2019 for regions of economic planning in Bulgaria (in Bulgarian).

[13] www.apc-de.cpm.

Received June 29, 2020

Engineering Sciences, LVII, 2020, No. 2 